\title{
Aspects of river eutrophication in Ireland
}

\author{
M. L. McGarrigle1
}

Keywords : Eutrophication, rivers, phosphorus, spreadsheet model, rainfall-discharge model, phosphate-discharge model.

In the absence of recognised criteria for phosphate in rivers, this paper attempts to arrive at an independant phosphate criterion value for Irish rivers as distinct from lakes. A comparison is made between biological assessments of river water quality and phosphate values at some 800 sites over a 3-year period. This analysis demonstrated that river eutrophication begins to be a problem when median annual « ortho-phosphate » (MRP) levels exceed $30 \mu \mathrm{g} \mathrm{P} \mathrm{1-1}$. A spreadsheet modelling technique aimed at predicting in-stream phosphate levels is illustrated by an example for the River Deel in County Mayo, Ireland. Regression equations link river flow rates or phosphate concentrations with daily rainfall figures in order to predict stream discharge and phosphate concentration on a 365-day basis. The equations - or similar site-specific equations - can be implemented using any of the standard spreadsheet packages for microcomputers.

\section{Aspects de l'eutrophisation des rivières en Irlande}

Mots clés : Eutrophisation, rivières, phosphore, modèle « spreadsheet », modèle pluie-débit, modèle phosphore-débit.

L'eutrophisation des cours d'eau est un problème différent du problème de l'eutrophisation des lacs. Il n'existe pas de critères pour le phosphate fluvial dans la C.E.C. Directive pour les poissons d'eaux douces. Cet article établit une comparaison entre les valeurs de phosphate et celles de la qualité biologique dans quelques 800 sites de rivières irlandaises, pour une période de trois ans. Cette analyse a montré que l'eutrophisation devient problématique quand le niveau annuel moyen d'ortho-phosphate (MRP) dépasse $30 \mu \mathrm{g} \mathrm{P} 1^{-1}$. Un modèle " spreadsheet " pour prédire les valeurs de phosphate est illustré par un exemple de la rivière Deel du comté de Mayo. Ce modèle utilise des équations de régression pour relier les débits ou les concentrations en phosphate avec les précipitations journalières. Cette méthode permet de prévoir l'écoulement et la concentration de phosphate pour les 365 jours de l'année. Ces équations - ou des équations semblables pour d'autres rivières - peuvent être mises en place avec un ordinateur PC et un logiciel « spreadsheet" comme Lotus 123 ou Microsoft Excel.

\section{Irish river water quality}

A biological monitoring programme for river water quality in Ireland covers some 4200 sites this includes virtually all Irish rivers of any significant size. Of $13470 \mathrm{~km}$ of river channel surveyed over $76 \%(1029 \mathrm{~km})$ is currently unpolluted. Serious organic pollution, due to poorly treated industrial or domestic discharges or point source agricultural releases, has declined significantly over the past 20 years since the survey began. Just $162 \mathrm{~km}$ of total channel length now falls into the seriously polluted category. Eutrophic stretches, however, have increased significantly over the past 20 years,

\footnotetext{
1.Environmental Protection Agency, The Mall, Castlebar, Co. Mayo, Ireland.

Texte d'une communication effectuée dans le cadre du Colloque - Limnologie appliquée et application de la Limnologie Besançon, Franche-Comté, 16-19 novembre 1992.
}

to the present situation where just over $22 \%$ of the total channel length (some $3000 \mathrm{~km}$ ) may be classified as eutrophic (McGarrigle et al., 1992). In Ireland this is of particular concern because most rivers are salmonid waters capable of supporting game fish such as trout, salmon or sea trout. Excessive macrophyte and algal growth in salmonid waters may cause dramatic diurnal variation in dissolved. oxygen (DO) levels which, at the night-time minimum, may result in the asphyxiation of oxygensensitive salmonid fish. Up to $50 \%$ of « fish-kills » reported in Ireland have been attributed to such phenomena in eutrophic waters during warm weather (Moriarty 1990).

\section{Setting phosphorus criteraia and stan- dards for rivers}

The EC «Freshwater Fish » Directive (C.E.C., 1978 ) is widely used in setting standards for river 
water quality: However, no values are included in the Annex I list of guideline or mandatory values for phosphorus in the case of rivers. As river eutrophication is possibly Ireland's most significant water quality problem it is important to have some criteria on which standards can be based. Here an attempt is made to determine such criteria.

A detailed comparison between biological results and routine chemical monitoring results was carried out for some 800 sites across Ireland for 1983-1985 (Toner et al. 1986). The biological survey determined whether individual sites were eutrophic or not through direct examination of flora and fauna. Sites were categorised, using the standard Irish Quality Rating System. This is a biological index system which is based primarily on macroinvertebrates but which also takes into account the extent of macrophyte and algal growth (Flanagan and Toner, 1972 ; McGarrigle et al. 1992). The Quality Rating System has nine "Q-Values » or separate categories - three unpolluted (Q5, Q4-5 and Q4), three eutrophic categories (Q3-4, Q3 and Q2-3) and three indicative of serious organic pollution (Q2, Q1-2 and Q1). A statistical analysis compared the reported minimum, median and maximum phosphate concentrations with the nine biological categories in order to give characteristic phosphate values for each Q-Value. The phosphate measure used in these surveys was molybdate reactive phosphorus (MRP) of unfiltered water samples. Table 1 gives the mean and median values for each category together with the standard deviation (see footnote to table for a more detailed explanation of the nature of these statistics). Comparative statistics for median and maximum Biochemical Oxygen Demand (BOD) and ammonia values are also given.

From this analysis it may be stated that if the annual median values for MRP are greater than $30 \mu \mathrm{g} \mathrm{P}-1$ then some degree of eutrophication is likely in the river in question. If pristine conditions are required median MRP values should be no greater than $15 \mu \mathrm{g} \mathrm{P}^{-1}$ - corresponding to the Q5 column in Table 1 . In setting effluent or receiving water standards based on these criteria, or in assessing how a particular river measures up to these criteria, a number of factors have to be considered.

- Summer values may be more important than annual median values in many cases. For example, in one river known to the author, an annual MRP median statistic of $35 \mu \mathrm{g} \mathrm{P}-1$ may mask prolonged periods during times of low flow when MRP levels reach levels of $100-400 \mu \mathrm{g} \mathrm{P} 1^{-1}$ due to a point phosphate source. In this case the eutrophication impact is significantly greater than might be expected from an annual median of $35 \mu \mathrm{g} \mathrm{P} 1^{-1}$. Phosphate is no longer a limiting nutrient during the critical growth periods in such a case. Thus, the ideal goal is to set effluent standards to such a level that, at times of low flow during summer, phosphate becomes or remains a limiting nutrient. This may imply that median summer levels in rivers should be held to about the $30 \mu \mathrm{g}$ P $1^{-1}$ mark.

- Phosphate uptake by the river's plant and algal biomass must be accounted for especially during the summer months. In assessing the eutrophication impact of effluents, mass- balanced estimates of final downstream concentrations are, therefore, preferable to direct in-stream phosphate measures. Thus, if the mass-balanced MRP values exceed $30 \mu \mathrm{g} \mathrm{P} 1^{-1}$ there may be a resulting eutrophication problem even though values of this magnitude may not actually be detected in regular chemical sampling programmes (due to uptake by plants). The case of a survey undertaken below the town of Trim on the River Boyne, Co. Meath, illustrates this point. A phosphate mass balance was carried out (with sodium as a conservative tracer) downstream of the town's sewage treatment plant (McGarrigle, unpublished data, 1989). It was found that combined plant/algal and sediment uptake amounted to almost $4 \mathrm{~kg} P$ per day with a $40 \%$ deficit in expected MRP concentrations observed.

- Diffuse phosphate sources are linked to rainfall events at critical times in the agricultural calendar. Rain following the spreading of animal manure or artificial fertiliser can lead to significant increases in stream phosphate concentrations. Here annual medians may lead to an underestimate of eutrophication impacts. Rainfall events may sporadically flush phosphate into a river system followed by sedimentation or by rapid assimilation by macrophytes and algae. If these events are sufficiently frequent critical biomass levels may be reached even though annual median values are quite low. Mean values, or flow-weighted means may be required in this situation when setting standards. The occurrence of high standard deviations in MRP concentration statistics may also be a pointer to the possibility of this 
Table 1. « Typical » values for phosphate as MRP, BOD and ammonia for each of nine Q-Value categories : median, mean and standard deviation (SD) of the reported values for 1983-1985. « $N$ » is the total number of sites per Q-Value Category.

Table 1. Valeurs « typique » pour le phosphate (MRP) pour la DBO et l'ammoniaque pour chacune des neufs « Valeurs-Q » : médianes, moyennes et déviation standard (SD) des valeurs reportées pour 1983-1985. « $\mathrm{N}$ » est le nombre total de sites pour chaque catégorie de "Valeurs-Q".

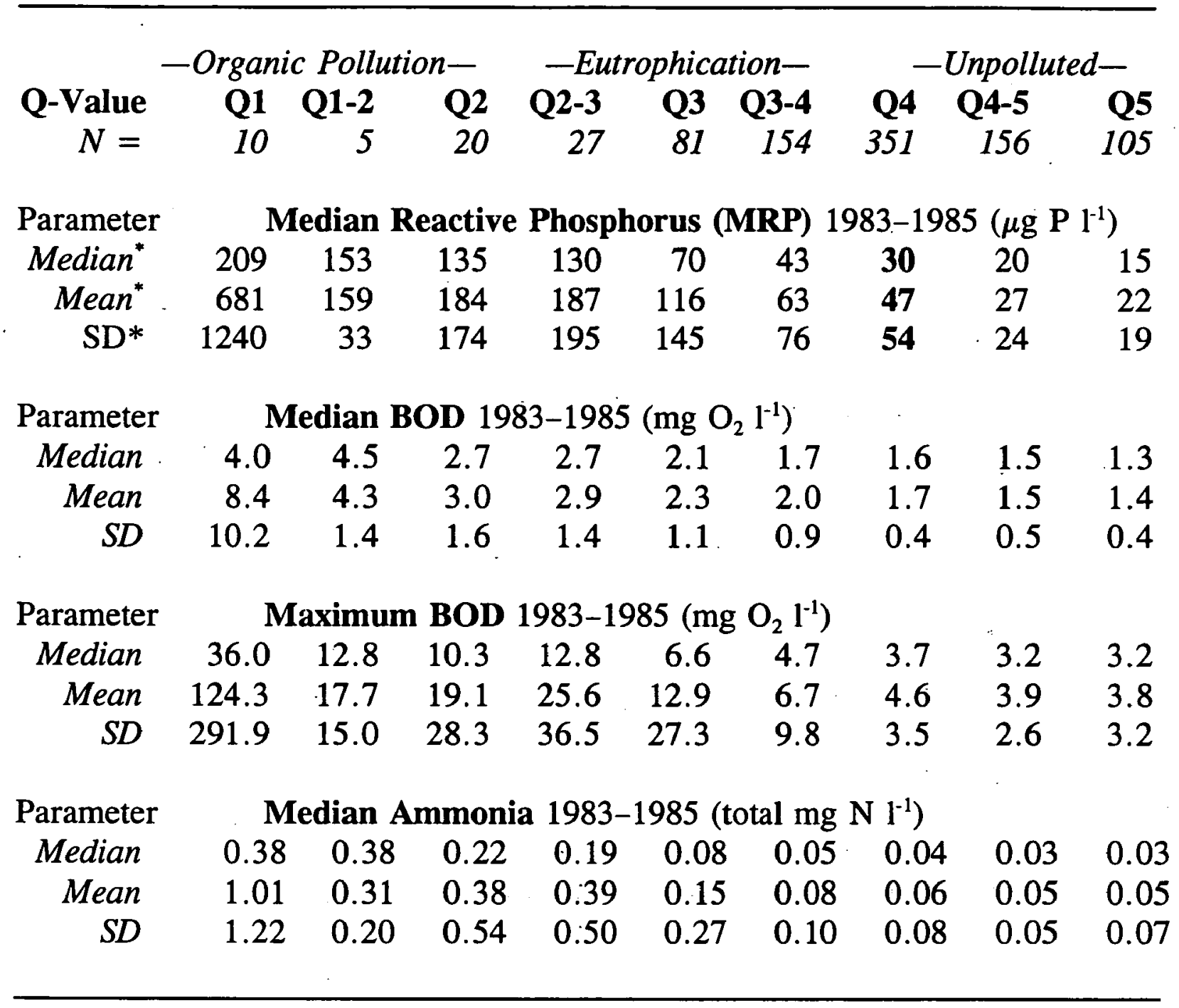

\footnotetext{
"For example: the statistics for the phosphate values corresponding to the 351 sites which had a Q-Value of Q4 - i.e. those sites having the lowest Q-Value regarded as unpolluted in the Irish Quality Rating System - are 30, 47 and $54 \mu \mathrm{g} \mathrm{P}^{-1}$, respectively, for Median, Mean and SD. The Median of $30 \mu \mathrm{g} \mathrm{P}^{-1}$ is the Median of the reported median reactive phosphorus (MRP) values for 351 sites which had a biological Q-Value of Q4. This Median is a statistic for the reported median value for up to 36 samples per site over the period 1983-1985 for $351^{\circ}(N)$ sites. Similarly, the Mean value of $47 \mu \mathrm{g} \mathrm{P} \mathrm{l}^{-1}$ is a statistic for the median values reported for these 351 sites and 54 is the corresponding standard deviation $(S D)$ for these median values.
}

type of problem. Simple $X Y$ plots of MRP vs. discharge or rainfall should also be used to determine whether diffuse runoff is a problem.

\section{A phosphate management modelling technique}

A 365-day spreadsheet model for assessing a river's ability to accept further phosphorus inputs without becoming eutrophic is now described. In a typical management situation, continuous discharge data and/or daily phosphorus measurements may not be available. Instead it is assumed that spot discharge measurements and grab sample results for phosphorus chemistry are available. The method involves establishing simple relationship based on standard regression techniques : 
- Discharge vs. rainfall regressions - good predictions for stream discharge rates can be obtained from regressions between spot flow measurements and the average of a few days prior rainfall (also taking time of year into account). Thus, a 365-day synthetic discharge record for the stream in question can be obtained based on data from the nearest rain gauges.

- P vs. discharge or rainfall regressions - these may be : (a) negatively correlated for point sources, (b) positively correlated for diffuse agricultural sources or (c) uncorrelated in cases where there are no major anthropegenic phosphorus inputs.

- A 365-day phosphorus concentration record is then established using regression equations in the case of (a) and (b) or by simple interpolation between spot measurements for (c) above. Case (b) will be treated in more detail below.

- The proposed new effluent or phosphorus source may be then mass-balanced on a dayby-day basis with the modelled concentrations.

\subsection{Discharge vs. rainfall predictions - River Deel}

River discharge (Q) was predicted from daily rainfall figures using regression analysis. The following example is based on data for the River Deel catchment, North Mayo, Ireland (Fig. 1). Spot staff gauge/discharge readings were made on 47 dates between 1 November 1990 and 31 October 1991 while taking water samples for chemical analysis. Daily rainfall data for three local meteorological stations (Ballina, Straide and Lahardane) were used to produce a set of regression equations. The average annual rainfall at these stations over the period in question ranged from 1000 to $1500 \mathrm{~mm}$. In deriving the regression equations a variety of rainfall functions for up to 7 days prior to the date for which flow information was available were screened. In all, 33 separate arithmetic functions of rainfall were tested in the regression analysis as independent variables (though generally only one at a time because of high intercorrelation between the variables). River discharge (Q) and Log of discharge were used as dependent variables. Separate " summer» and " winter" regressions were derived in order to account for evapotranspiration effects. The derived equations predicting river discharge from rainfall are shown in Fig. 2.

Figure 3 compares the observed discharges with predicted by these equations for the period 1 November 1990 to 31 October 1991. Hindcasts for 27 spot discharge measurements were also made for the period 1980-1989 and these are shown in Fig. 4. These latter were not included in the derivation of the regression equations and, thus, act as validation for the regression equations. In general, good agreement was obtained. It is felt that under - or over - estimated individual peaks in discharge are due to phase-lag problems and that a full 365-day prediction should give a realistic picture of discharge variation, albeit possibly out of phase at times. Thus, a simple regression analysis can give a useful 365-days synthetic discharge record which will fill gaps in the record for a river which is not continuously gauged. A 2-year, daily synthetic discharge grap is shown in Fig. 5 for the period from 1 January 1990 to 31 December 1991, based on equations (1), (2) and (3) in Fig. 2.

\subsection{Phosphate vs. discharge/rainfall predictions - diffuse sources}

Example equations for the prediction of phosphate in the case of diffuse agricultural runoff are derived here using a similar methodology to that described for the discharge vs. rainfall regression analysis. Diffuse agricultural phosphate runoff gives rise to positive correlations between discharge rate and phosphate concentration. This phenomenon has been noted in two of the tributaries of Lough Conn. The phosphorus regressions in Fig. 2 are also based on data for the period 1 November 1990 to 31 October 1991 at the River Deel station Knockadangan Bridge. Separate « winter " and " summer » equations were again required to give a more accurate prediction.

These equations combine to give the backpredictions for MRP shown in Fig. 6 giving a correlation of $r=0.760$ between observed and predicted values for $n=50$ observations - which is highly significant, albeit with a degree of scatter about the central tendency.

\subsection{Spreadsheet model structure}

The 11-column by 365-row spreadsheet model for the discharge and MRP calculations is shown 
in Table 2. Colums A to D hold the date and rainfall values for the three meteorological stations used in deriving the equations. Columns $\mathrm{E}$ and $\mathrm{F}$ contain regression formulae for discharge and MRP. In the case of the discharge prediction three regression equations are combined with a seasonal choices and a check for heavy rain in summer. In pseudo code :

IF (date is between May to October) then

If $\mathrm{R}_{\text {Day-12 }}>5 \mathrm{~mm}$

Endif
Then $\mathrm{Q}=0.063+0.041 * \mathrm{R}_{\text {Day-123 }}$

Else $Q=0.046+0.923 * R_{\text {Day }-123}$
ELSE (November to April)

$$
\mathrm{Q}=1,93+2.71 * \mathrm{R}_{\text {Day-1 }}
$$

\section{ENDIF}

The corresponding Lotus 123 formula for a single cell in e.g. column $\mathbf{E}$, row 28 , will be typed as follows : (although the formula will be in continuous form on one line)

$$
\begin{gathered}
\text { @IF(((@MONTH(A28) > 4)* }(@ M O N T H(A 28)<11)), \\
\text { @IF(@AVG(B26..D27) > 5,063+0.41*@AVG(B25..D27), } \\
\left.0.046+0.923^{*} @ A V G(B 25 . . D 27)\right), \\
\left.1.93+2,71^{*} @ A V G(B 27 . . D 27)\right)
\end{gathered}
$$

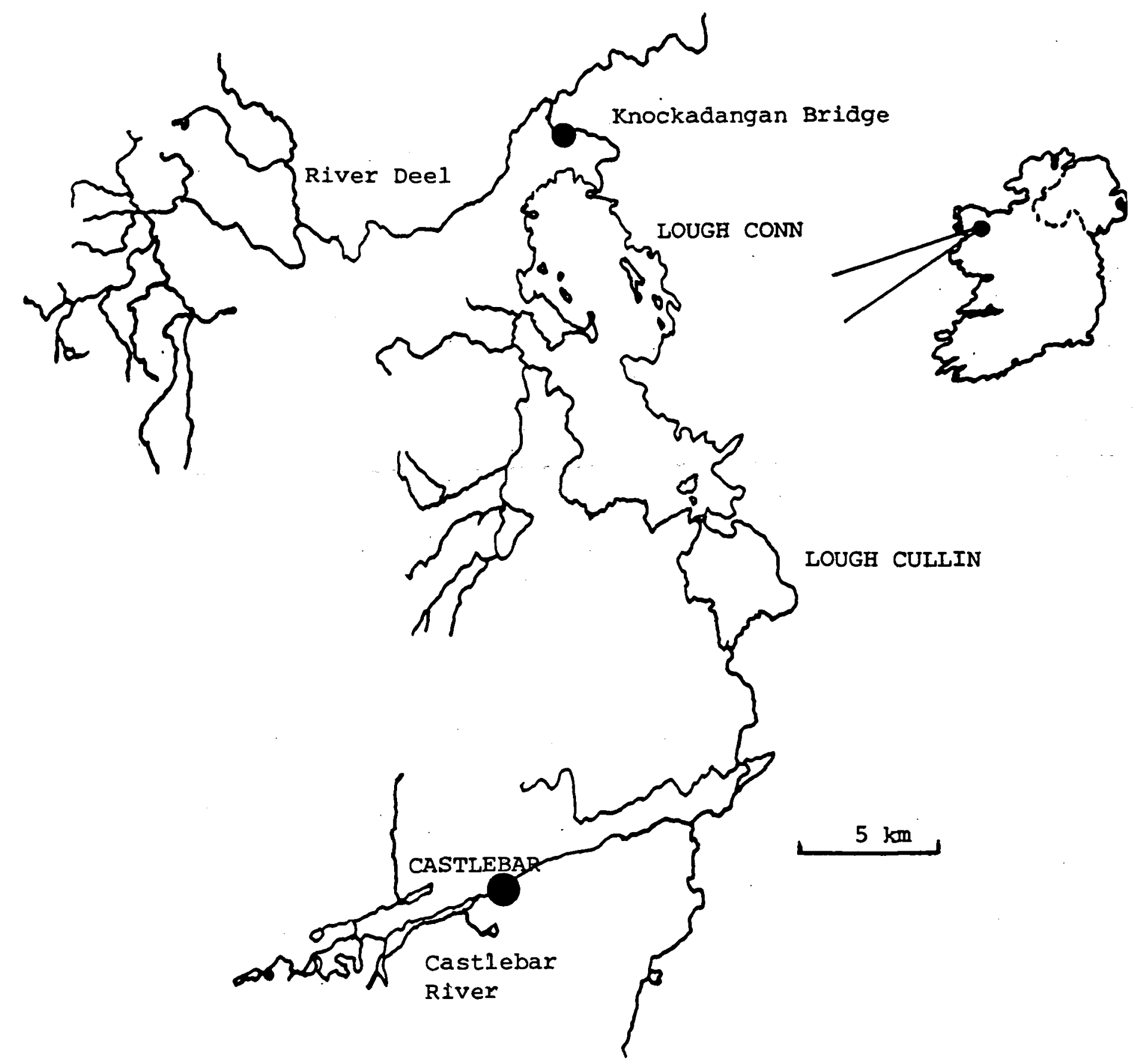

Fig. 1. Study location showing Loughs Conn and Cullin, Co. Mayo, the Rivers Deel and Castlebar with the Knockadangan Bridge sampling site.

Fig. 1. Carte de la région étudiée avec les Loughs Conn et Cullin, Co. Mayo, les rivières Deel et Castlebar. Le Pont de Knockadangan est le site d'échantillonnage. 


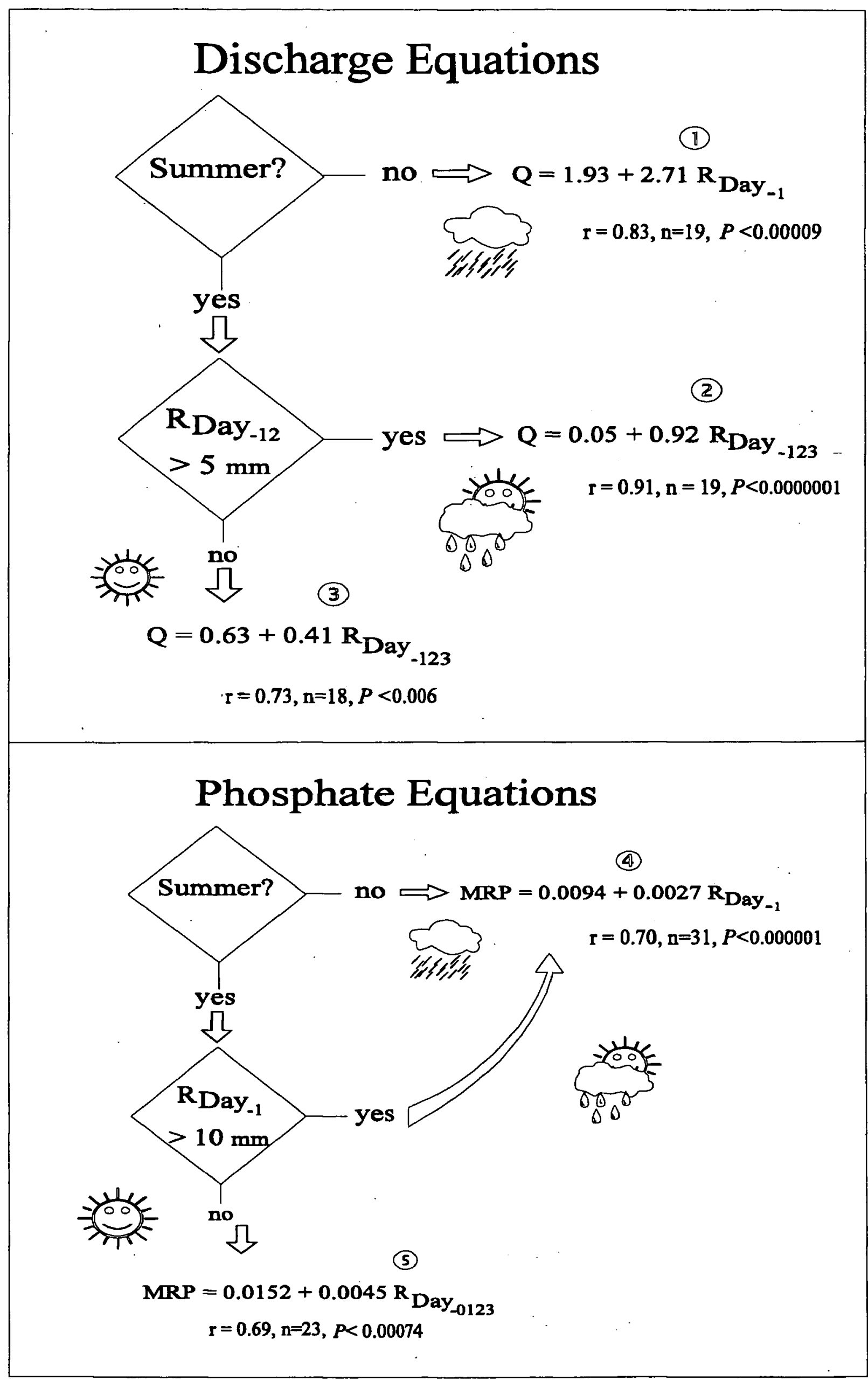

Fig. 2. Regression equations for prediction of discharge $\left(Q\right.$ in $\left.\mathrm{m}^{3} \mathrm{~s}^{-1}\right)$ from rainfall $\left(\mathrm{R}_{\mathrm{Day}-n}\right.$ in $\mathrm{mm}$ ) and for prediction of $M R P$ (mg $P^{-1}$ ) from rainfall for River Deel at Knockadangan Bridge - a location affected by diffuse agricultural runoff. $R_{D a y-n}$ is rainfall (in $\mathrm{mm}$ ) on the $n$th day(s) prior to the date of the predicted discharge or phosphate value.

Fig. 2. Les équations de régressions pour prédire le débit $\left(Q\right.$ en $\left.\mathrm{m}^{3} \mathrm{~s}^{-1}\right)$ et le $\mathrm{MRP}$ (en $\left.\mathrm{mg} \mathrm{P}^{-1}\right)$ à partir de la hauteur des précipitations $\left(R_{\text {Day- } n}\right.$ en $\mathrm{mm}$ ) pour la rivière Deel au pont de Knockadangan, zone riche en effluents agricoles diffus. La hauteur des précipitations est donnée par : $R_{\text {Day- } n}$ avec hauteur en $\mathrm{mm}$ pour le(s) $n$ jours avant la date de prédiction. 


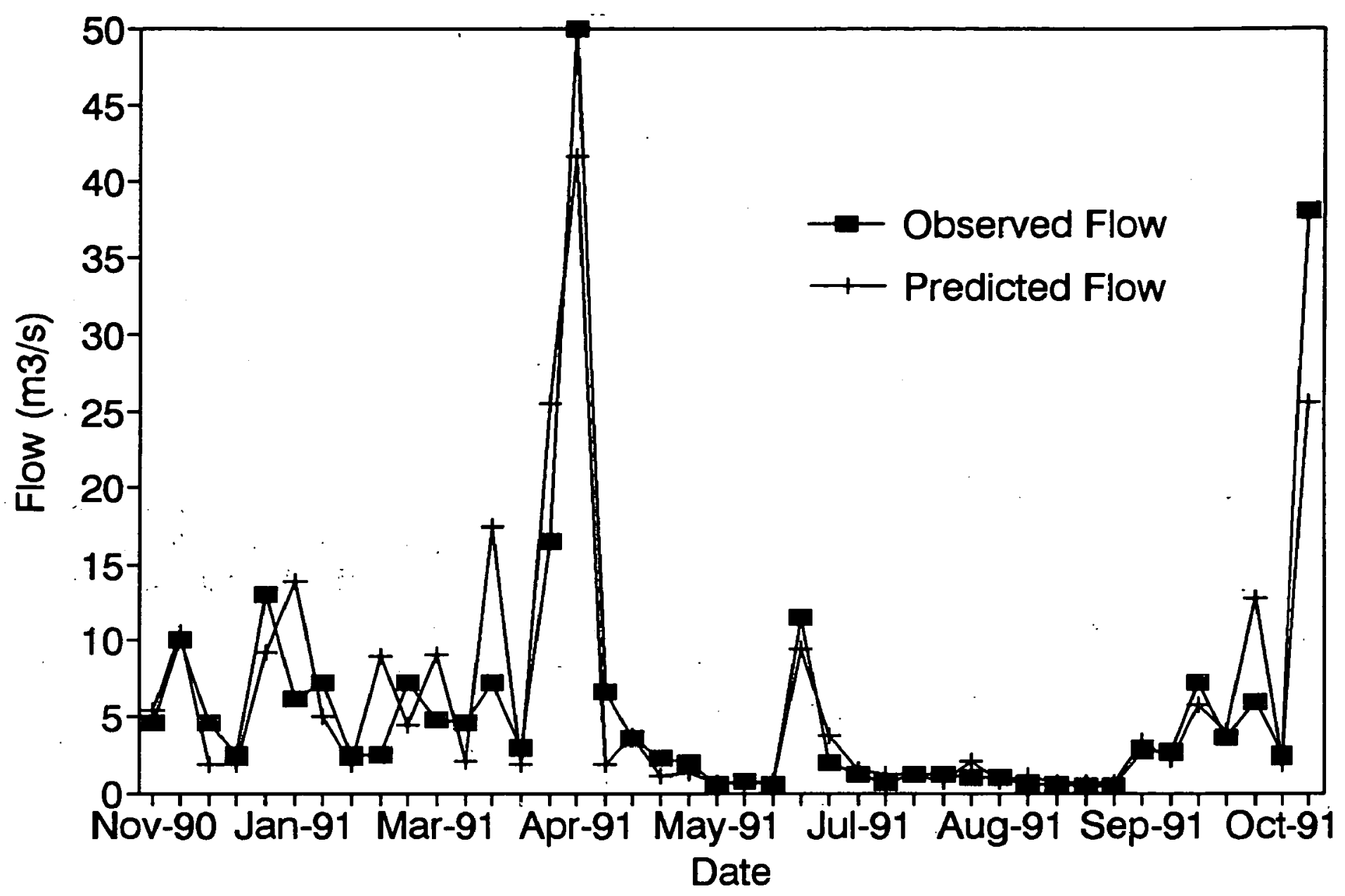

Fig. 3. Observed and rainfall-predicted discharge in $\mathrm{m}^{3} \mathrm{~s}^{-1}$ for River Deel, Knockadangan Bridge, based on regression equations described in the text for 1 November 1990 to 31 October 1991.

Fig. 3. Débit observé en $\mathrm{m}^{3} \mathrm{~s}^{-1}$ et prédit par la hauteur des précipitations pour la rivière Deel, au pont de Knockadangan, à partir des équations de régressions (voir texte) du $1^{\text {er }}$ Novembre 1990 au 31 Octobre 1991.

Table 2. Section of spreadsheet model to predict river flow $\left(\mathrm{m}^{3} \mathrm{~s}^{-1}\right)$ (col E) and MRP levels $\left(\mu \mathrm{g} P \mathrm{1}^{-1}\right)(\mathrm{col} F)$ from date and rainfall $(\mathrm{mm})(\mathrm{A}-\mathrm{D})$. MRP load $\left(\mathrm{mg} \mathrm{P} \mathrm{s}^{-1}\right)$ is calculated as $\mathrm{E} \times \mathrm{F}$. Columns $\mathrm{H}$ and I represent flow rate ( $\left.\mathrm{m}^{3} \mathrm{~s}^{-1}\right)$ and $\mathrm{MRP}$ concentration $\left(\mu \mathrm{g} \mathrm{P}^{-1}\right.$ ) in a hypothetical effluent and $\mathrm{J}$ is the mass-balanced MRP downstream of the effluent. See Fig. 2 for model equations.

Tableau 2. Partie du modèle « spreadsheet » pour prédire le débit $\left(\mathrm{m}^{3} \mathrm{~s}^{-1}\right)(\mathrm{col} \mathrm{E})$ et les valeurs de MRP $\left(\mu \mathrm{g} P \mathrm{1}^{-1}\right)$ (col F) à partir de la date et de la hauteur des précipitations $(\mathrm{mm})(\mathrm{A}-\mathrm{D})$. Le flux de MRP (mg P $\left.\mathrm{S}^{-1}\right)$ est calculé par $\mathrm{E} \times \mathrm{F}$. Les colonnes $\mathrm{H}$, et I représentent le débit $\left(\mathrm{m}^{3} \mathrm{~s}^{-1}\right)$ et la concentration de MRP $\left(\mu \mathrm{g} \mathrm{P}^{-1}\right)$ pour un effluent industriel hypothétique et $\mathrm{J}$ est le MRP calculé à l'aval de l'effluent. Pour les équations, voir Fig. 2.

\begin{tabular}{|c|c|c|c|c|c|c|c|c|c|c|}
\hline & A & B & C & $\mathrm{D}$ & $\mathrm{E}$ & $\mathbf{F}$ & $\mathbf{G}$ & $\mathrm{H}$ & I & $\mathrm{J}$ \\
\hline 1 & & $\operatorname{Raj}$ & afall & $(\mathrm{mm})$ & Pred & Pred & Pred & Effl & $\operatorname{Effl}$ & Balanced \\
\hline $\begin{array}{l}2 \\
3\end{array}$ & Date & BALL & STRA & LAHA & FLOW & MRP & Load & Flow & MRP & MRP \\
\hline 4 & $01-J a n-90$ & 2.3 & 4.0 & 0.0 & 1.9 & 9 & 18 & 0.03 & 500 & 24 \\
\hline 5 & $02-J a n-90$ & 0.0 & 0.1 & 0.0 & 2.9 & 20 & 60 & 0.03 & 500 & 35 \\
\hline 6 & $03-\operatorname{Jan}-90$ & 0.0 & 0.0 & 0.8 & 2.2 & 10 & 21 & 0.03 & 500 & 25 \\
\hline 7 & 04-Jan-90 & 2.9 & 2.9 & 8.8 & 8.6 & 9 & $8 i$ & 0.03 & 500 & 24 \\
\hline 8 & $05-J a n-90$ & 0.9 & 0.7 & 0.0 & 18.7 & 17 & 325 & 0.03 & 500 & 32 \\
\hline 9 & $06-J a n-90$ & 9.5 & 13.3 & 17.5 & 52.2 & 11 & 591 & 0.03 & 500 & 26 \\
\hline 10 & $07-J a n-90$ & 0.5 & 0.7 & 0.8 & 42.3 & 46 & 1940 & 0.03 & 500 & 61 \\
\hline 11 & $08-\operatorname{Jan}-90$ & 1.3 & 1.0 & 0.0 & 2.0 & 11 & 23 & 0.03 & 500 & 26 \\
\hline 12 & $09-\operatorname{Jan}-90$ & 16.6 & 15.4 & 21.8 & 24.5 & 12 & 298 & 0.03 & 500 & 27 \\
\hline 13 & $10-J a n-90$ & 8.7 & 2.5 & 13.4 & 14.7 & 52 & 757 & 0.03 & 500 & 66 \\
\hline 14 & $11-J a n-90$ & 2.2 & 3.9 & 4.2 & .4 .9 & 16 & 80 & 0.03 & 500 & 31 \\
\hline 15 & $12-J a n-90$ & 0.3 & 0.3 & 0.7 & 2.0 & 20 & 41 & 0.03 & 500 & 35 \\
\hline 16 & $13-\operatorname{Jan}-90$ & 7.6 & 6.0 & 7.9 & 1.9 & 10 & 20 & 0.03 & 500 & 25 \\
\hline 17 & $14-J a n-90$ & 2.2 & 8.0 & 3.0 & 1.9 & 26 & 50 & 0.03 & 500 & 40 \\
\hline 18 & 15-Jan-90 & 8.3 & 3.3 & 4.4 & 1.9 & 31 & 60 & 0.03 & 500 & 46 \\
\hline 19 & $16-\operatorname{Jan}-90$ & 5.5 & 8.0 & 21.0 & 1.9 & 18 & 36 & 0.03 & 500 & 33 \\
\hline 20 & $17-J a n-90$ & 3.5 & 2.4 & 3.2 & 1.9 & 31 & 60 & 0.03 & 500 & 46 \\
\hline 21 & $18-J a n-90$ & 14.4 & 12.8 & 18.2 & 1.9 & 16 & 31 & 0.03 & 500 & 31 \\
\hline
\end{tabular}




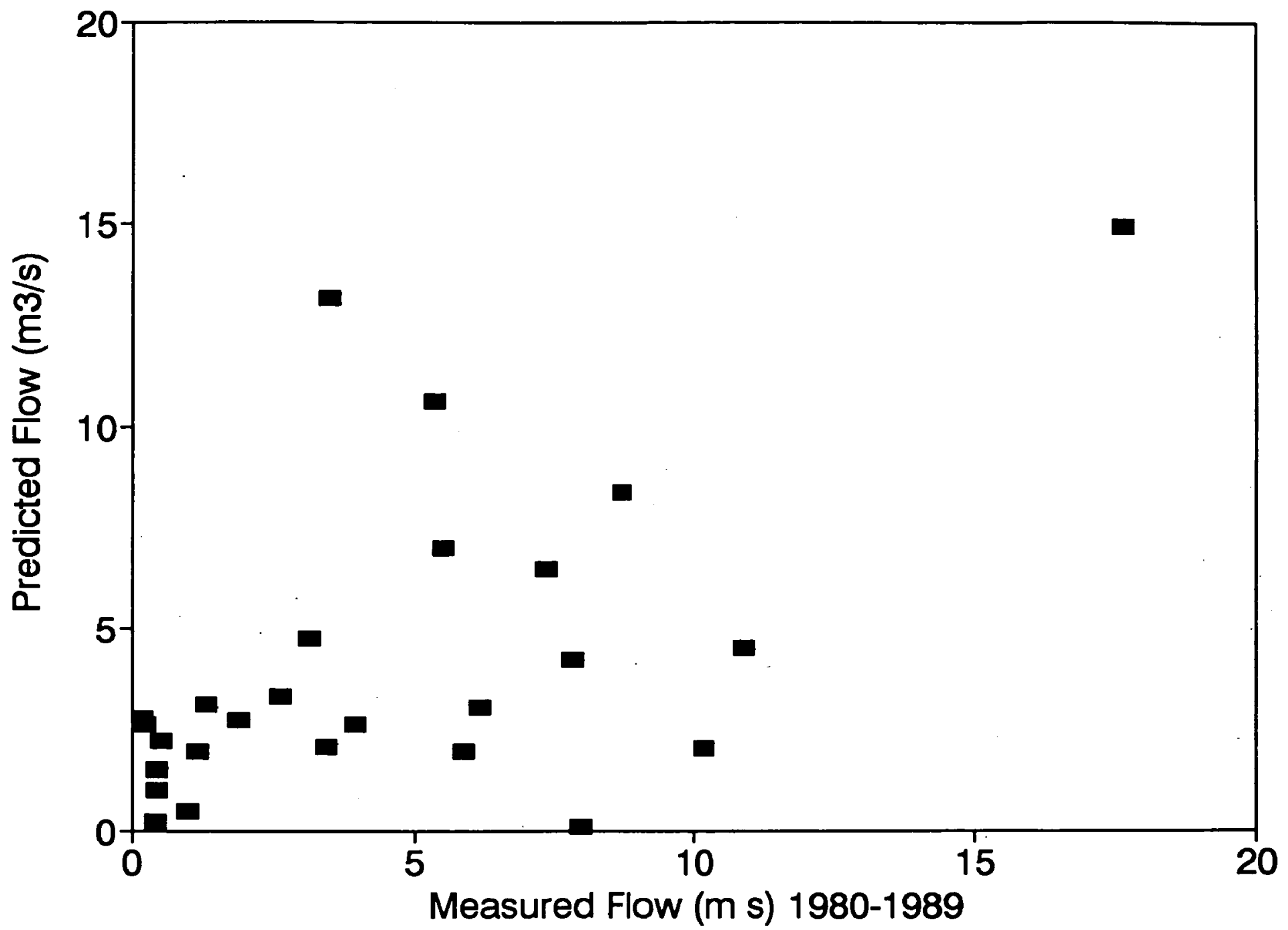

Fig. 4. Observed and rainfall-predicted flow rates for River Deel, Knockadangan Bridge, based on regression equations described in the for the 10-year period 1980 to 1989.

Fig. 4. Débit observé en $\mathrm{m}^{3} \mathrm{~s}^{-1}$ et prédit par la hauteur des précipitations pour la rivière Deel, au pont de Knockadangan, à partir des équations de régression (voir texte) pour la période de 10 années, de 1980 à 1989.

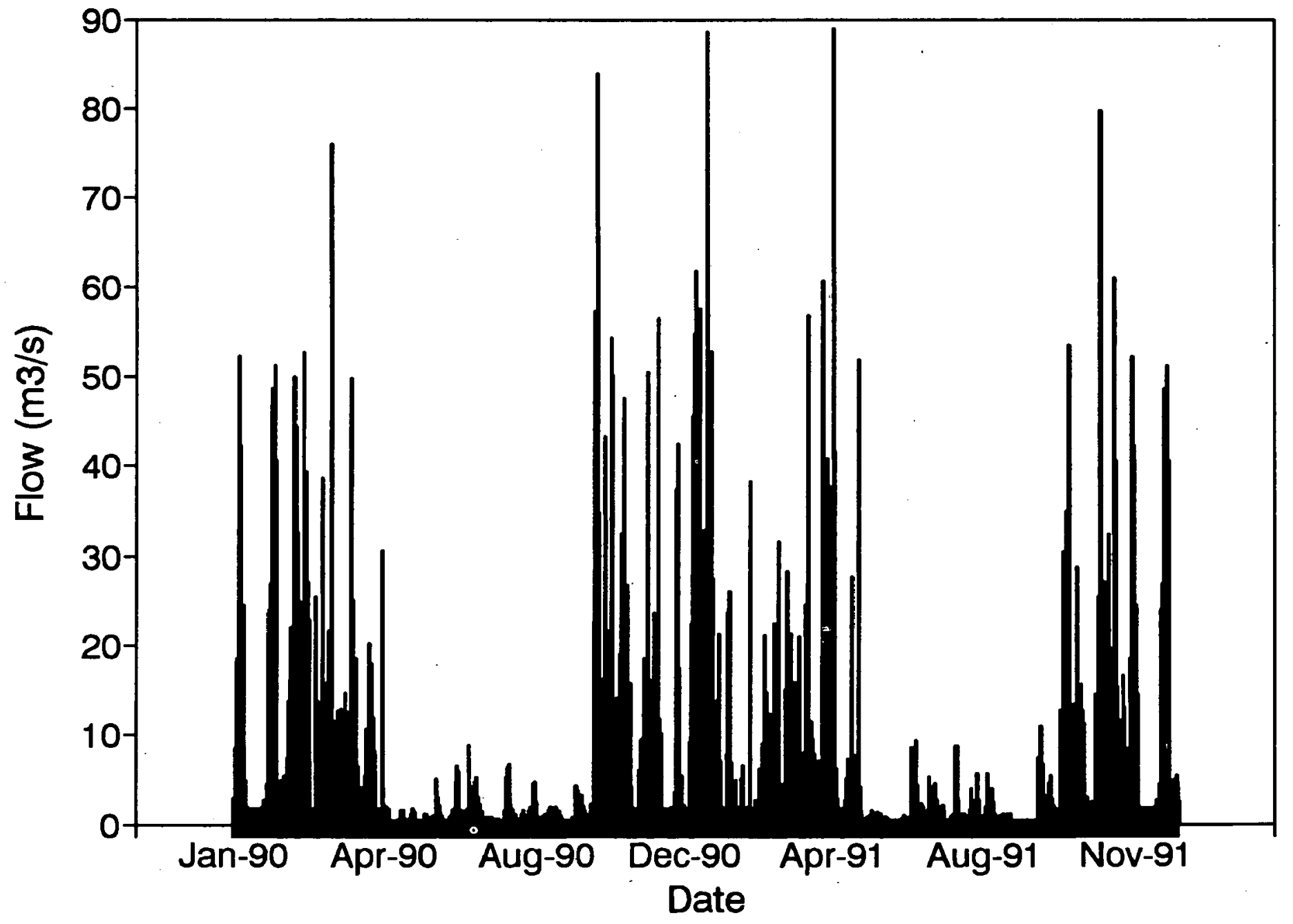

Fig. 5. A 2-year daily flow prediction for River Deel site based on the regression equations described in the text and shown in Fig. 2. Fig. 5. Débit journalier prédit au cours de 2 ans pour la rivière Deel à partir des équations de régressions décrites dans le texte et montrées Fig. 2. 


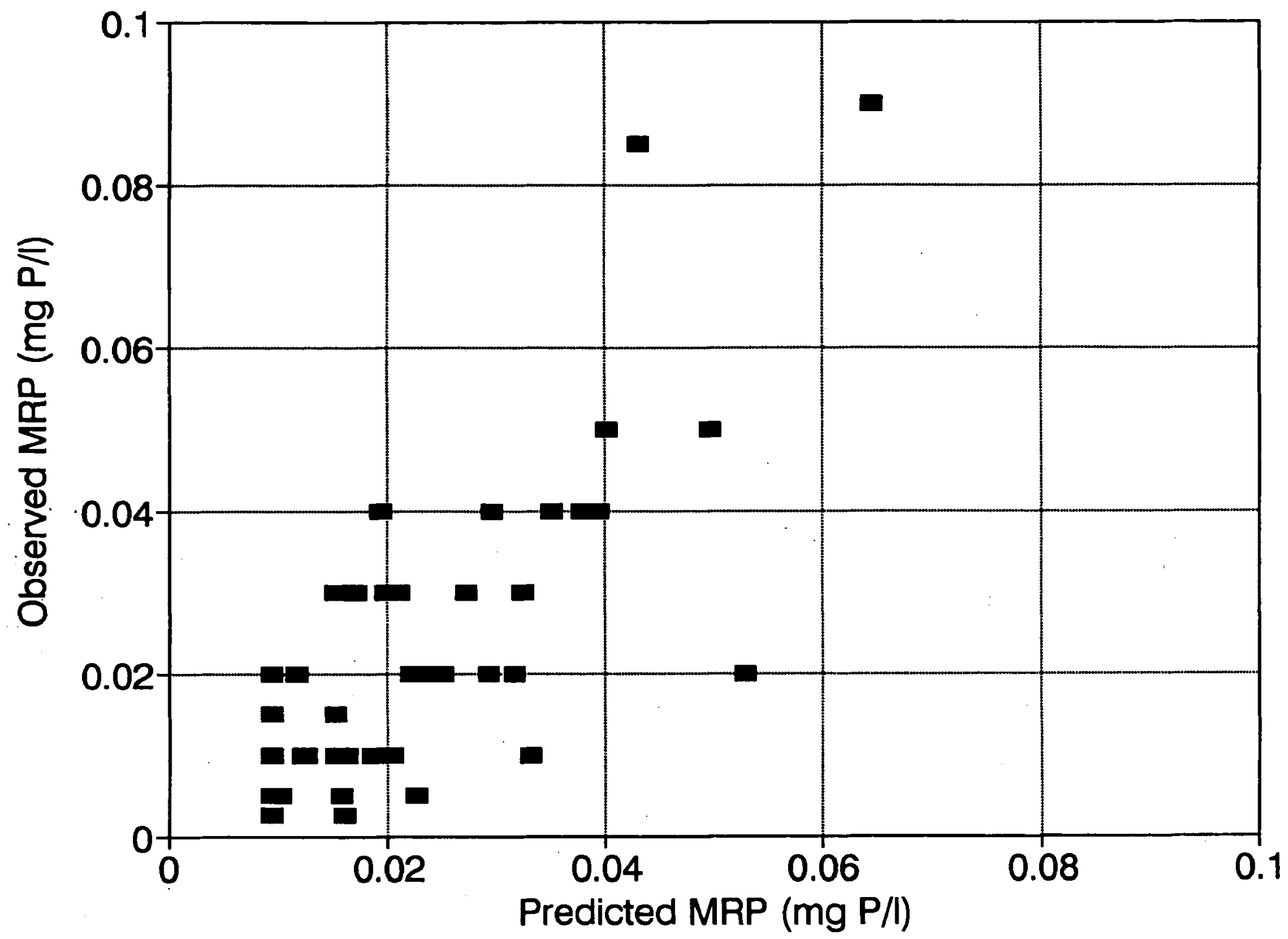

Fig. 6. Observed vs rainfall-predicted MRP values for River Deel, Knockadangan Bridge, 1 November 1990 to 31 October 1991. Fig. 6. Valeurs de MRP observées et prédites à partir des précipitations pour la rivière Deel au pont de Knockadangan du $1^{\text {ex }}$ Novembre 1990 au 31 Octobre 1991.

Column $\mathrm{G}$ is a simple multiplication of cells in $\mathrm{E}$ and $\mathrm{F}$ giving daily MRP loadings. Colums $\mathrm{H}$ and I represent predicted or actual effluent discharge and effluent MRP concentration. Column J contains the standard mass balance formula for downstream MRP

$$
M R P=\frac{f^{*} c+F^{*} C}{(f+F)} \text {. }
$$

where $f$ and $F$ denote discharge in the effluent and river, respectively, and $c$ and $C$ represent their MRP concentrations. Inspection or plotting of the massbalanced values in column $\mathbf{J}$ will reveal whether the set limit for phosphorus has been exceeded. Counting of exceedances may be automated by putting following formula in the next column $\mathrm{K}$ :

$@ \operatorname{IF}(($ colJ $>30), 1,0)$

where colJ represents the cell on the same row in col $\mathrm{J}$. This will place a « 1 » next to every value which is greater than $30 \mu \mathrm{g} \mathrm{m}^{-1}$. Considerations such as time of the year at which peak values occur and the frequency of values in excess of the criteria vs. any standards which have been set for the stream may then be taken into account. Simulated sampling programmes of varying intensity can be created using the 365-day synthetic record of phosphorus concentrations with Monte-Carlo techniques. Spreadsheet functions such as the randon number generator function @RAND combined with the logical function @IF0 can be combined to produce a set of random samples by placing the formula :

$$
@ \mathrm{IF}((@ \mathrm{RAND}<12 / 356), \mathrm{col} F, 0)
$$

at the top of, say, colum $M$. The number of valid samples can be counted by placing the following formula in column $\mathrm{N}$ to its right :

$$
@ \operatorname{IF}((\operatorname{col} M>0), 1,0)
$$


where colF and colM indicate individual cell names entered directly or pointed to when typing the formula. When both these are replicated 365 times down their respective columns they will provide approximately 12 random sample values from the 365-day synthetic record for phosphate. A @SUM0 and @STD0 placed at the bottom of these columns will produce a set of statistics which may be compared with those for the full 365-day record. This random Monte Carlo sampling can be stratified to mimic monthly $(30.5 / 365)$ or weekly sampling $(52 / 265)$ in a variety of ways - in a more or less elegant fashion depending on the ingenuity of the spreadsheet operator. The user can then recalculate the spreadsheet and copy statistics such as mean and standard deviation into a separate working area on the spreadsheet. This will rapidly build up a picture of the effectiveness of any particular sampling regime and its likely accuracy in assessing the true situation in the river.

All of these calculations are easily carried out with any reasonably sophisticated spreadsheet such as Lotus 123 or Microsoft's Excel. The command syntax may vary slightly depending on the spreadsheet in use but the principles should be widely applicable.

\section{General conclusions}

Control of river eutrophication is seen as one of the most important tasks facing Irish water quality managers. Limits of $30 \mu \mathrm{g} \mathrm{P}^{-1}$ seem quite low by the standards of a few years ago but they now seem inescapable if eutrophication is to be brought under control in Irish salmonid waters. Desktop computers now enable scientists and managers to make increasing use of the capabilities of powerful spreadsheet and statistical packages in eutrophication research and control. It is hoped that the examples given here will encourage experimentation in this field.

\section{Acknowledgements}

Sections of this work were carried out for the Committee on Eutrophication of Lough Conn, established by Mayo County Council in 1992. The phosphate analyses were carried out at the Regional Water Laboratory, Castlebar ; (Dr. P. Larkin), water samples were collected by the Northwestern Fisheries Board (Mr. V. Roche) ; flow measurements were made by the hydrometric staff at the Regional Water Laboratory (Mr. H. McGinley). The work was part-funded by the EC STRIDE programme for Ireland.

\section{References}

C.E.C. (Council of the European Communities) 1978. Council directive of 18 July 1978 on the quality of fresh waters needing protection or improvement in order to support fish life (78/659/EEC). Official Journal of the European Communities, No. L 222/1.

Flanagan P.J. \& Toner P.F. 1972. - The National Survey of Irish Rivers. A Report on Water Quality, An Foras Forbartha, Water Resources Division, Dublin, $213 \mathrm{p}$.

McGarrigle M.L., Lucey J. \& Clabby K.C. 1992. - Biological Assessment of River Water Quality in Ireland. In River Water Quality - Ecological Assessment and Control, 371-394. Eds. Newman P.J., Piavaux M.A. \& Sweeting R.A., Commission of the European Communities, EUR 14606 EN-FR, 751 p. Luxembourg.

Moriarty C. 1990. - Fish Kills in Ireland in 1990. Fishery Leaflet 149. Dublin, Department of the Marine, Roinn na Mara.

Toner P.F., Clabby K.J., Bowman J.J. \& McGarrigle M.L. 1986. - Water Quality in Ireland, The Current Position : Part One : General Assessment. An Foras Forbartha, WR/G15, ISBN 185053060 2, Dublin, 116 p. 